\title{
Tulevan - ja samalla nykyisen - koulutuspolitiikan eräitä ydinkysymyksiä
}

Suomalaisessa koulutuspolitiikassa tapahtuu edelleen. Keskeisinä tapahtumisen ja kehittämisen painopistealueina peruskoulussa ja lukiossa ovat edelleen opetussuunnitelmat, ammatillisessa koulutuksessa opetussuunnitelmien lisäksi lainsäädännön yhtenäistäminen, uusien peruslinjojen perustaminen ja eräät määrällisen suunnittelun kysymykset sekä korkeakoulutuksessa perustutkintojen, täydennyskoulutuksen ja tieteellisten jatkotutkintojen edelleen kehittäminen. Aikuiskoulutuksessa ollaan monivuotisen kokonaissuunnitteluvaiheen jälkeen pääsemässä toisaalta koulutuksen monimuotoiseen käytännön toteuttamiseen, toisaalta yksityiskohtaisemman jatkosuunnittelun vaiheeseen.

Yhteiskunnan ja ennenkaikkea uuden teknologian aiheuttamien koulutusmuutosten suorittamisen tarve ei ole vähentynyt - päinvastoin. Muutosten ainakin pintapuolinen nopeutuminen saattaa ruveta aiheuttamaan hämmennyksen lisäksi kohtalokkaita näköharhoja. Kun koulutuskokonaisuudet näyttäisivät olevan yhä hankalammin sekä hahmoteltavissa että hallittavissa, saattaa riskiksi tulla liukuminen helpommalle tielle. Suoritetaan sinänsä usein välttämättömiä ad hoc -toimia, mutta toimien laaja-, syvä- ja pitkävaikutteisten seurausten pohdinta saattaa jäädä liian vähälle.

Elinikäisen/jatkuvan koulutuksen periaatetta on tarjottu koulutuksen ja koulutusjärjestelmien kehittämisen sekä päämääräksi että kokonaisstrategiaksi. Jatkuvan koulutuksen toimikunta piti vuonna 1983 ilmestyneessä eräänlaisessa perusmietinnössään keskeisenä koulutuksen kehittämisperiaatteena jatkuvan koulutuksen ideaa. Opetusministeriön asettama jatkuvan koulutuksen projektiryhmä on konkretisoinut edelleen asiaa viime vuoden lopulla valmistuneessa muistiossaan (opetusministeriön työryhmien muistioita 1986:1). Seuraava esitys pohjautuu ryhmän työhön ja mainittuun muistioon.

\section{Valtioneuvoston periaatepäätös}

Muistiossa tiivistetään jatkuvan koulutuksen periaatteen toteuttaminen koulutusjärjestelmässämme ehdotukseksi valtioneuvoston periaatepäätökseksi. Jotta koulutusjärjestelmäämme voidaan suunnitelmallisesti ja riittävän pitkäjänteisesti kehittää tulevaisuudessakin, valtioneuvoston tulisi ehdotuksen mukaan tehdä periaatepäätös, jonka kymmenen kohtaa on muistiossa otsikoitu seuraaviksi: 1 . Lapsuus- ja nuoruusiän koulutus, 2. koko väestön koulutustason nostaminen, 3. koulutus ja sen ympäristö, 4. koulutusjärjestelmän avoimuus ja opiskeluesteiden poistaminen, 5 . koulutuksen sisältöjen ja menetelmien kehittäminen, 6. kattava tutkintojen järjestelmä, 7 . opetus- ja hallintohenkilöstön koulutus ja opintoneuvonta, 8. koulutuksen hallinto, suunnittelu ja tutkimus, 9. jatkuvan koulutuksen periaatteen toteuttamisvastuu, yhteistyö ja työnjako sekä 10. toteuttamisen käynnistäminen ja voimavarat.

Jatkuvan koulutuksen toimikunnan vuoden 1983 mietintöön tukeutuen periaatepäätösehdotuksen kunkin kohdan pääsisältö on muistiossa kiteytetty olennaisimpaan. Käytettävissä oleva palstatila ei anna mahdollisuutta puuttua noihin sisältöihin. 


\section{Tutkintojen järjestelmä}

Tässä kirjoituksessa kiinnitän huomiota vain päätösehdotuksen 6 . kohtaan, tutkintojen järjestelmään, jota projektiryhmä on tarkastellut erikseen laajemmin. Ehdotus kattavasta tutkintojen järjestelmästä perustuu jatkuvan koulutuksen strategioille ja toimii ikäänkuin jatkuvan koulutuksen yhtenä käytännön (laajana) sovelluksena koulutusjärjestelmässä.

Tutkintojen nykytilanne maassamme on varsin epämääräinen ja koordinoimaton. Tutkintoja on koulutukseen aikaa myöten kehittynyt melkoisesti, mutta vailla systemaattista kokonaisotetta.

Eräänä yleislähtökohtana on pidettävä sitä että opinnoilla ja oppimisella on aina itseisarvonsa. Toisaalta sekä opiskelija eri elämäntilanteissaan että yhteiskunta hyötyvät siitä, että koulutusta nivelletään yhteen myös tutkintoja sekä niiden yhteismitallisuutta ja vertailtavuutta kehittämällä.

Tutkinnot jaotellaan 1. peruskoulutuksen, 2. lisäkoulutuksen sekä 3. koulutusjärjestelmän ulkopuolisiin tutkintoihin.

Kattavan tutkintojen järjestelmän aikaansaamisen perusedellytyksiin kuuluu, että koulutusjärjestelmien eri osat mahdollisimman tarkoituksenmukaisesti niveltyvät toisiinsa. Opiskelijalle on tärkeää, että opinnot eivät missään vaiheessa johda "umpiperään", vaan voivat koostua eri aikoina ja eri paikoissa sekä eri koulutusmuodoissa ja -asteilla suoritetuista opinnoista ja opintokokonaisuuksista. Eri koulutusten ja koulutusmuotojen raja-aitoja on alennettava.

Tutkintojen ja niihin liittyvien opintokokonaisuuksien yhteismitallisuus merkitsee sitä, että eri oppilaitoksissa ja eri oppilaitosmuodoissa suoritetut samansisältöiset ja -asteiset sekä -kestoiset tutkinnot tai niiden osat voidaan rinnastaa toisiinsa. Vastaavuus ja korvaavuus tulevat arvioitaviksi silloin, kun opiskelija siirtyy opiskelemaan toiselle alalle tai jatkaa opintojaan ylemmällä koulutusasteella. Opintonsa keskeyttäneen tai toiselle alalle hakeutuvan ei pitäisi joutua tarpeettomasti suorittamaan aiempiin opintosuorituksiin nähden päällekkäisiä opintoja. Tältä pohjalta voidaan vähentää päällekkäiskoulutusta ja opintojen keskeyttämistä. Vastaavuus- ja korvaavuusmahdollisuudet saatetaan koskemaan nykyistä selkeämmin/myös työssä oppimista.

Vastaavuuden ja korvaavuuden toteamiseksi tulee luoda riittävän selkeät yleisohjeet, joi- den nojalla 'oppilaitoksille siirretään mahdollisimman paljon harkintavaltaa yksittäisen opiskelijan kannalta yksilöllisten, mutta samalla tiettyihin yleisiin kriteereihin perustuvien ratkaisujen tekemiseen.

Tutkintojen osia voidaan korvata tiettyinä kokonaisuuksina, kuten jonkin oppiaineen oppimäärinä tai kursseina tai sen tarkoin rajattuina sisältöalueina. Korvattavana kokonaisuutena voi olla myös opintojen tiettyyn ajanjaksoon sisältyvä kokonaisuus, esimerkiksi lukuvuosi tai lukukausi. Eri koulutusmuodoissa suoritettuja opintoja voidaan soveltuvilta osin koota tutkinnoiksi.

Eriasteista perus- ja lisäkoulutusta sekä työelämää lähennetään toisiinsa. Siksi työssä suoritettavaa toimintaa ja esimerkiksi harjoittelujaksoja tulee tarkastella koulumuotoista opetusta vastaavina silloin, kun ne kiinteästi tukevat tai syventävät opetusta. Näin voidaan lyhentää alalla työskentelevien tai työskennelleiden opiskeluaikaa ja lisäkoulutuksen hankkiminen tulee aikuisopiskelijalle helpommaksi. Korvaavuusperiaatetta voidaan käyttää myös alaan sopiviin harrastuksiin.

Aikuisopiskelijan kannalta on keskeistä, että hän voi virallisesti hyödyntää aikaisempien opintojensa lisäksi muutkin eri tavoin hankitut tietonsa ja taitonsa. Työssä saavutettu taito ja kokemus on voitava soveltuvin osin lukea hyväksi tutkinnoissa.

Aikuisopiskelijan kannalta on lisäksi olennaista se, missä suhteessa erilaiset opintosuoritukset ovat koulujärjestelmän virallisiin tutkintoihin. Järjestelmän on oltava sellainen, että se mahdollistaa erilaisten opintosuoritusten vastaavuuden vertailun.

Aikuisten peruskoulutuksen tutkintojen tulisi olla nimikkeiltään ja perustavoitteiltaan sekä tuottamaltaan kelpoisuudelta samoja koulutusjärjestelmän tutkintojen kanssa. Perustutkintoon edettäessä sekä nuorisoasteen koulutuksessa että aikuiskoulutuksessa tulee voida suorittaa tavoitteisia osatutkintoja. Opintojen keskeyttämisen vähentämiseksi on erityisesti aikuisopiskelijoita ajatellen tarpeen muodostaa opinnot sellaisiksi, että päättötutkintoon voidaan edetä välitavoittein.

Aikuisten tulee voida suorittaa keskiasteen yleissivistävän ja ammatillisen peruskoulutuksen tutkintoja tai niiden osia (oppimääriä ja kursseja) yksityisoppilaana (tarvittaessa myös luennoilla käyden), iltalinjoilla, työllisyyskoulutuksessa sekä etäopintoina ja oppisopimusteitse koulutusorganisaatioita nykyistä joustavammin käyttäen. 
Lisäkoulutuksen tutkintojen tulisi mahdollisuuksien mukaan kytkeytyä koulujärjestelmän tutkintoihin. Lisäkoulutuksen tutkinnoissa otetaan huomioon suoritukset erilaisilla kursseilla ja esim. vapaan sivistystyön harrastustavoitteiset opinnot, vaikka ne eivät olisikaan alun perin tutkintoon tähtääviä. Esimerkiksi teollisuuden ammattioppilaitosten, ammattiopistojen ja muissa selkeää jatko- ja täydennyskoulutustehtävää suorittavissa instituutioissa hankittu koulutus sekä työllisyyskurssit tulee ottaa huomioon opiskelijan suorittaessa ylempitasoisia opintoja.

Jatko-opinnot ja täydennyskoulutus tulee mahdollisuuksien mukaan suunnitella ja organisoida opiskelijakohtaisesti monimuoto-opetuksen periaatteita noudattaen.

\section{Mitä edellytetään opetussuunnitelmilta?}

Tiettyyn tutkintoon tähtäävää koulutusta varten laaditaan pääsääntöisesti vain yksi opetussuunnitelma tai yhdet opetussuunnitelman perusteet, joihin sisällytetään kyseistä koulutusastetta ja aikuiskoulutusta koskevia sovellusohjeita. Siten esimerkiksi aikuisten ammatillista iltaopetusta varten ei laadita erillistä opetussuunnitelmaa, jos kysymyksessä olevalle alalle on jo laadittu opetussuunnitelma nuorisoastetta varten.

Koulutusjärjestelmän tutkintojen sisältämä oppiaines tulee jakaa perusoppiainekseen ja eriytyvään tai valinnaiseen oppiainekseen. Esimerkiksi ammatillisen koulutuksen koulutusammatissa perusoppiaineksen osuus olisi vähintään - alan vaatimuksista riippuen $-2 / 3$ tutkinnon sisältämästä koko oppiaineksesta ja loput opiskelijan erityistaipumusten, paikkakuntakohtaisen tarpeen tai muun syyn johdosta valinnaista oppiainesta.

Perus-, keski- ja korkea-asteen koulutuksen oppiaines tulee laatia siten, että keskinäinen vertailu on mahdollista. Samalla selvitetään eri koulutusasteiden yhteinen oppiaines. On myös selvitettävä lukion ja ammatillisen koulutuksen yleissivistävän oppiaineksen yhteiset sisällöt ja suunniteltava ne niin, että vertailu on soveltuvin osin mahdollista. Ammatillisessa koulutuksessa ja lukiossa annettavaa yleissivistävää opetusta korvaavaa koulutusta tulee voida järjestää tarkoituksenmukaisella tavalla myös kansanopistoissa ja kansalais- ja työväenopistoissa sekä muissa vapaan sivistystyön toimintamuodoissa.
Keskiasteen yleissivistävän ja ammatillisen sekä korkea-asteen koulutuksen opintosuoritusten vastaavuus ja hyväksilukeminen on opetussuunnitelmia kehitettäessä selvitettävä myös yksityisoppilasjärjestelmien ja erillisten tutkintotilaisuuksien kannalta.

Tutkintojen järjestelmän hallinnosta todettakoon seuraavaa:

- Tutkintojen järjestelmän hallintoa hoitavat mahdollisimman pitkälle jo olemassa olevat elimet.

- Kaikki tutkintoihin liittyvä päätöksenteko, jolla ei ole valtakunnallisesti yhtenäistävää merkitystä, tulee siirtää alimmalle mahdolliselle hallinnon tasolle. Oppilaitos päättää $\mathrm{mm}$. yksityisoppilaiden otosta sekä opiskelijakohtaisten opetussuunnitelmien laadinnasta.

- Tutkintojen järjestelmän ylin hallinto, koordinointi ja suunnittelu sijoittuu yhdessä muun koulutuksen kehittämistä koskevan työn kanssa opetuksen keskushallintoon.

Jatkuvan koulutuksen projektiryhmä on nyt tehnyt kokonaisehdotuksensa. Tutkintojen järjestelmää pitää ryhtyä kehittämään asteittain. Jatkokehittäminen vaatii lähivuosien aikana monenlaista yksityiskohtaisempaa selvitys- ja suunnittelutyötä, jota tullaan tekemään hallinnon eri tahoilla ja tasoilla. Opetusministeriön avuksi on ehdotettu perustettavaksi tutkintoasiain neuvottelukunta, jonka tehtävänä olisi koordinoida tutkintojen järjestelmän kehittämistä jatkuvan koulutuksen periaatteen suunnassa.

\section{Lähteet}

Jatkuvan koulutuksen toimikunnan mietintö, Kom. miet. 1983:62

Jatkuvan koulutuksen projektiryhmän muistio, opm:n työryhmien muistioita 1986:1 